\title{
Short-term Aluminum Stress Differentially Affects the Photochemical Efficiency of Photosystem II in Highbush Blueberry Genotypes
}

\author{
Marjorie Reyes-Diaz ${ }^{1}$, Miren Alberdi, and Maria de la Luz Mora ${ }^{2}$ \\ Centro de Ciencias y Biotecnología de Recursos Naturales, Universidad de La Frontera, \\ Casilla 54-D, Temuco, Chile
}

\begin{abstract}
AdDITIONAL INDEX wORDs. carotenoids, chlorophyll fluorescence, PSII, cultivars, root growth, Vaccinium corymbosum
Abstract. Aluminum (Al) toxicity is a major agronomic problem in acid soils. Most studies regarding Al stress focus on phenomena occurring in the roots; however, less is known about the effects of Al stress on photosynthetic apparatus functionality. Our aim was to rank three highbush blueberry (Vaccinium corymbosum) cultivars according to their tolerance to acid and Al stresses. Additionally, the levels of Al toxicity for highbush blueberry were established. 'Brigitta', 'Legacy', and 'Bluegold' were grown in a greenhouse in hydroponic solutions containing different Al concentrations ( $(0,25,50,75$, and $100 \mu \mathrm{M})$ for 0 to $48 \mathrm{~h}$ and were allowed to recover (without $\mathrm{Al}$ ) over $24 \mathrm{~h}$. In all Al-treated cultivars, root growth inhibition was found at the highest Al treatment. However, 'Brigitta' also showed root growth up to $75 \mu \mathrm{M}$ Al. Photochemical parameters decreased substantially due to Al treatments in 'Bluegold' (up to $98 \%$ inhibition) and 'Legacy' (up to $80 \%$ inhibition) without total recovery. In contrast, 'Brigitta' showed a better photosystem II performance and root growth than the other cultivars. These results suggest that 'Brigitta' is the best cultivar for use in acid soils with Al toxicity, followed by 'Legacy'. 'Bluegold' was highly sensitive to Al stress. In addition, Al toxicity levels for blueberries depend on the genotype studied.
\end{abstract}

In areas with high rainfall, soluble nutrients and other basic elements are solubilized from soils, with a concomitant $\mathrm{pH}$ decrease. Organic matter mineralization also results in a release of hydrogen ions $\left(\mathrm{H}^{+}\right)$, decreasing the $\mathrm{pH}$ of soils. $\mathrm{H}^{+}$releases $\mathrm{Al}$ as $\mathrm{Al}^{3+}$ predominantly retained by the negative charges of clay minerals in equilibrium with the $\mathrm{Al}^{3+}$ of the soil solution. Thus, the quantity of $\mathrm{Al}^{3+}$ in the soil solution is augmented with soil acidity to levels that can be toxic to plants (Hede et al., 2001). Aluminum toxicity is a major agronomic problem in acid soils. Acid soils may account for as much as $50 \%$ of the world's potentially arable land (Dahlgren et al., 2004). This problem is exacerbated by the current extensive use of ammonium fertilizers and acid rain (von Uexkull and Mutert, 1995). Most studies regarding Al stress are focused on phenomena occurring in the roots because the effects of $\mathrm{Al}$ manifest themselves in the plant root system first (Barceló and Poschenrieder, 2002; Delhaize and Ryan, 1995). Many reports indicate that acidification generates an increase in $\mathrm{Al}$ concentration as $\mathrm{Al}^{3+}$ in the soil solution (Jarvis, 1987). This results in root growth reduction (Mora et al., 2004, 2005; Tamás et al., 2006) and sensitivity to Al toxicity (Kochian, 1995), reducing

\footnotetext{
Received for publication 2 Sept. 2008. Accepted for publication 15 Oct. 2008. We would like to thank Professor Walter Lobos, blueberry specialist from the Facultad de Ciencias Agrarias (Universidad de La Frontera, Temuco, Chile) for valuable assistance and advice on the selection of the genotypes Highbush Blueberry used in this work, Dr. Helen Lowry (Queen's University, Canada) for revising the language to the manuscript, Dr. Luis Corcuera for helpful criticism of the manuscript, Bicentenary Program in Science and Technology PSD-26 and FONDECYT $\mathrm{N}^{\circ} 1080372$ Projects for financial support, Yesenia Rojas for technical assistance, and the helpful suggestions made by the editor and anonymous reviewers to improve the quality of this manuscript.

${ }^{1}$ Instituto de Agroindustria, Facultad de Ingeniería, Ciencias y Administración, Universidad de La Frontera, Casilla 54-D, Temuco, Chile.

${ }^{2}$ Corresponding author. E-mail: mariluz@ufro.cl.
}

crop yields (Bolan et al., 2003; Kochian, 1995; Matsumoto, 2000).

Little is known as to whether the early effects of $\mathrm{Al}$ stress on roots are reflected in the functionality of the photosynthetic apparatus. Restricted shoot growth also becomes evident only after root growth is limited by exposure to toxic levels of $\mathrm{Al}^{3+}$ in the rooting environment (Rengel, 1996). Comparatively less information exists about the effects of $\mathrm{Al}^{3+}$ on leaves than on roots. In leaves, Al toxicity induces chloroplast malformations, even though high amounts of Al may not be detected in this organelle, indicating indirect effects on chloroplast functioning (Moustakas et al., 1995). In effect, decreases in total chlorophyll content and photosynthetic rates accompanied by a partial inhibition of photosynthetic electron transport in photosystem II (PSII) in response to $\mathrm{Al}^{3+}$ have been reported in some species (Chen et al., 2005a, 2005b; Chen, 2006; Peixoto et al., 2002; Pereira et al., 2000). Alterations in the photosynthetic apparatus due to stress affect the metabolism and productivity of crops (Rao and Cramer, 2003).

Differential uptake of $\mathrm{Al}^{3+}$ by roots among crop genotypes could account for differences in tolerance to this metal (Delhaize et al., 1993). Nevertheless, conflicting results have been reported regarding differences in $\mathrm{Al}$ accumulation and tolerance by different genotypes. For example, wild species that grow in acidic soils are frequently very resistant to Al stress and can accumulate high concentrations of $\mathrm{Al}$ in their leaves $(>1 \%$ of dry weight), whereas cultivated species such as Oryza sativa and Secale cereale cannot (Kochian, 1995).

Species of commercial interest such as Medicago sativa, Hordeum vulgare, Solanum lycopersicum, and Brassica napus are sensitive to Al, whereas Triticum aestivum and Zea mays genotypes exhibit high variability in their sensitivity (Kochian, 1995; Piñeros et al., 2005). Thus, plant response to Al toxicity is highly dependent on the species or cultivar studied (Barceló 
and Poschenrieder, 2002; Giannakoula et al., 2008; Kochian, 1995).

Al toxicity seems to be significant in limiting plant growth and production in acidic soils derived from volcanic ash (Andisols) in southern Chile (Borie and Rubio, 2003; Mora et al., 2006). The preponderant current agronomic activity in this region is highbush blueberry cultivation. Although Vaccinium corymbosum is adapted to acidity (Ireland and Wilk, 2006), the physiological response to the interaction between acid substrate and $\mathrm{Al}$ and its accumulation in plant organs in different genotypes of this species remains unknown. Our aim was to rank three highbush blueberry cultivars according to their tolerance to short-term acid and $\mathrm{Al}$ stresses by measuring root growth, photochemical fluorescence parameters, Al, and pigment contents. This study is relevant because highbush blueberry is cultivated in Chile in acidic soils with high potential for Al toxicity.

\section{Materials and Methods}

Plant material. The three most frequently cultivated genotypes of $V$. corymbosum ('Brigitta', 'Legacy', and 'Bluegold') in southern Chile were selected for this study (Guerrero, 2006). One-year-old saplings (15 cm in height) of these cultivars growing in a solid substrate (1 oat: 1 shell sawdust: 1 pine needles by volume) were provided by the Maquehue Station of the Universidad de La Frontera (Temuco, Chile). Saplings were conditioned in plastic boxes filled with $18 \mathrm{~L}$ of Hoagland's nutrient solution for 1 week (Hoagland and Arnon, 1959). The physiological status of saplings during conditioning was controlled by chlorophyll fluorescence analyses by determination of the maximum quantum yield $\left(\mathrm{F}_{\mathrm{v}} / \mathrm{F}_{\mathrm{m}}\right)$ as described below. Due to the $\mathrm{F}_{\mathrm{v}} / \mathrm{F}_{\mathrm{m}}$ values remaining in the range of healthy leaves (near 0.8) (Björkman and Demmig 1987), the time of conditioning was considered adequate. After conditioning, saplings were transferred to a hydroponic solution of $\mathrm{CaCl}_{2}(0.5 \mathrm{~mm})$ containing $\mathrm{Al}$ as $\mathrm{AlCl}_{3}$ in concentrations of 0 , 25, 50, 75, and $100 \mu \mathrm{M} \mathrm{Al} \mathrm{(treatment} \mathrm{solution)} \mathrm{for} \mathrm{different}$ times ( 24 and $48 \mathrm{~h}$ ) in a greenhouse. The solutions were prepared with sterile deionized water and were filter sterilized through $0.2-\mu \mathrm{m}$ diameter pore filters. The $\mathrm{pH}$ of the control (without $\mathrm{Al}$ ) and $\mathrm{Al}$ treatment solutions was monitored and was adjusted daily to 4.5 using $0.1 \mathrm{M} \mathrm{HCl}$ with a high accuracy portable $\mathrm{pH}$ meter (model pH-0.13; Hi-Tech-Instruments, Shanghai, China). Environmental conditions in the greenhouse were $25 / 20{ }^{\circ} \mathrm{C}$ (day/night), 16/8 h (light/dark) light periods, $70 \%$ relative air humidity, and photosynthetic photon flux $(P P F)$ densities of $120 \mu \mathrm{mol} \cdot \mathrm{m}^{-2} \cdot \mathrm{s}^{-1}$. This light intensity was similar to that used for maintenance in Maquehue Station, where plants were previously cultivated. Solutions were aerated with an aquarium pump and were changed every $2 \mathrm{~d}$. After $48 \mathrm{~h}$ of treatment, the cultivars were transferred to $\mathrm{CaCl}_{2}$ solution without $\mathrm{Al}$ for $24 \mathrm{~h}$ (recovery treatment). The recovery treatment permits discrimination between Al-tolerant, -sensitive, and -intermediate genotypes (Raman et al., 2002). There were nine saplings per $\mathrm{Al}$ treatment in a split-plot design. The experiment was run twice. At the start of the experiment (control without $\mathrm{Al}$ ) and after each treatment, physiological, chemical, and morphological analyses of roots and leaves were performed as indicated below.

Root GROWTH. Before treatment, the initial sizes of the longest primary roots of nine saplings in the control and $\mathrm{Al}$ treatment groups of the three cultivars were measured and recorded. Thereafter, the root length after 24 and $48 \mathrm{~h}$ of treatment and at recovery was monitored.

Aluminum content in Plants. Leaves and roots of the samples were separated and dried by placing them in a $70{ }^{\circ} \mathrm{C}$ forced-air oven for $48 \mathrm{~h}$. After weighing, samples were ashed at $500{ }^{\circ} \mathrm{C}$ for $8 \mathrm{~h}$ and were treated with $2 \mathrm{M}$ hydrochloric acid. Al was quantified using a simultaneous multielement atomic absorption spectrophotometer (model 969; UNICAM, Cambridge, UK) as described by Sadzawka et al. (2004).

Pigment Determinations. Total chlorophylls and total carotenoids were measured in extracts of completely expanded nonshaded leaves by a spectrophotometer (Genesys 5; Spectronic New York) at 663, 646, and $470 \mathrm{~nm}$. Pigments were extracted with ethanol $96 \%$ and concentrations were calculated according to Lichtenthaler and Wellburn (1983).

Chlorophyll Fluorescence parameters. Chlorophyll fluorescence parameters were used to determine the photochemical efficiency of PSII in leaves. The basic protocol of Reyes-Díaz et al. (2005) was followed. Fluorescence of attached nonshaded leaves was measured using a portable pulse-amplitude modulated fluorimeter (FMS 2; Hansatech Instruments, Norfolk, UK). Completely expanded leaves of the three cultivars were dark-adapted for $30 \mathrm{~min}$ (to obtain open centers) with leaf-clips with a mobile shutter plate. The fiber optic and its fiber optic adapter were then attached to a ring located $10 \mathrm{~mm}$ above the leaf sample. Different light pulses (see below) were applied following standard routines programmed into the machine. Signal recording and calculation were performed on a personal computer using data analyses and control software (Hansatech Instruments). Minimal fluorescence $\left(\mathrm{F}_{0}\right)$ was determined by applying a weak-modulated light $\left(0.4 \mu \mathrm{mol} \cdot \mathrm{m}^{-2} \cdot \mathrm{s}^{-1}\right)$ and maximal fluorescence $\left(\mathrm{F}_{\mathrm{m}}\right)$ was induced by a short pulse $(0.8 \mathrm{~s})$ of saturating light $\left(9000 \mu \mathrm{mol} \cdot \mathrm{m}^{-2} \cdot \mathrm{s}^{-1}\right)$. After $10 \mathrm{~s}$, actinic light $\left(120 \mu \mathrm{mol} \cdot \mathrm{m}^{-2} \cdot \mathrm{s}^{-1}\right)$ was turned on to obtain fluorescence parameters during steady-state photosynthesis. Saturating pulses were applied after steady-state photosynthesis had been reached to determine maximal fluorescence in light-adapted leaves $\left(\mathrm{F}_{\mathrm{m}}{ }^{\prime}\right)$ and steady-state fluorescence $\left(\mathrm{F}_{\mathrm{s}}\right)$. Finally, the actinic light was turned off and a 5-s far-red (FR) pulse was applied immediately to obtain minimal fluorescence in light-adapted leaves $\left(\mathrm{F}_{0}{ }^{\prime}\right)$. In this article, we used the definitions of fluorescence parameters [maximum quantum yield of the PSII $\left(\mathrm{F}_{\mathrm{v}} / \mathrm{F}_{\mathrm{m}}\right)$, effective quantum yield of the PSII ( ${ }_{\Phi}$ PSII), electron transport rate (ETR), and nonphotochemical quenching (NPQ)] as described by Maxwell and Johnson (2000). ${ }_{\Phi}$ PSII was calculated as $\left(\mathrm{F}_{\mathrm{m}}{ }^{\prime}-\mathrm{F}_{\mathrm{s}}\right) / \mathrm{F}_{\mathrm{m}}$ '. ETR was calculated as $P P F \times 0.5 \times{ }_{\Phi} \mathrm{PSII} \times 0.84$. NPQ was calculated as $\left(F_{m}-F_{m}{ }^{\prime}\right) / F_{m}$ ' (Maxwell and Johnson 2000).

Statistical ANAlyses. Reported values of chlorophyll fluorescence parameters correspond to the mean of four to six individual replicates for each cultivar and experiment, six individual replicates for root growth, and three individual replicates for $\mathrm{Al}$ and pigment contents. Data were subjected to a two-way analysis of variance (ANOVA; where the factors were $\mathrm{Al}$ treatments and time), with repeated measurements for one factor (cultivars) (Quinn and Keough 2006). A Tukey test was used to identify those values with significant differences. Both analyses were performed with Sigma Stat software (version 2.0; SPSS, Chicago). Differences between the values were considered significant at $P \leq 0.05$. 


\section{Results}

No root elongation was observed in the $V$. corymbosum cultivars investigated under the effect of the highest $\mathrm{Al}$ treatment (Fig. 1). Root growth was observed in the $75 \mu \mathrm{M}$ of $\mathrm{Al}$ treatment in 'Brigitta' and 'Legacy' (around 6\%; $P \leq 0.05$ ), but not in 'Bluegold'. The largest elongation without Al was observed in 'Brigitta' roots (23\% and $32 \%)$ at both times and after the recovery treatment, respectively, when compared with their initial values $(P \leq 0.05$; Fig. 1$)$.

Roots showed higher $\mathrm{Al}$ content $(63 \%-92 \%)$ than leaves in all the cultivars (Fig. 2), with the highest percentages frequently being found after $48 \mathrm{~h}$ of treatment. $\mathrm{Al}$ content decreased after $24 \mathrm{~h}$ of recovery treatment, with the exception of 'Brigitta' (Fig. 2). In all cultivars, a significant increase in $\mathrm{Al}$ content was found at each time in Al-treated roots, with respect to the controls and the recovery period $(P \leq 0.05)$. Root Al content in 'Brigitta' was similar in all $\mathrm{Al}$ treatments (Fig. 2), whereas in 'Bluegold', it increased with Al concentration. For 'Legacy', Al content significantly decreased after the recovery treatment
(Fig. 2). A statistically significant interaction between $\mathrm{Al}$ treatments and time was found in roots in 'Legacy' $(P<$ $0.001)$ and 'Bluegold' $(P=0.021)$.

In leaves, all cultivars increased their $\mathrm{Al}$ content at the higher $\mathrm{Al}$ treatments with respect to the control $(50 \%-75 \%$; $P<$ $0.05)$. The highest content in leaves was found in 'Brigitta' in all $\mathrm{Al}$ treatments at $24 \mathrm{~h}(75 \%)$ and $48 \mathrm{~h}(67 \%)$ with respect to the controls (Fig. 2). After the recovery period, 'Brigitta' $(55 \%)$, and to a lesser degree 'Legacy' (40\%), showed higher Al content than the controls. By contrast, 'Bluegold' had similar Al content than its respective control (Fig. 2). Statistically significant interactions were found between $\mathrm{Al}$ treatments and times in all cultivars $(P \leq 0.001)$.

Differences between the concentrations of total chlorophylls $(\mathrm{Chl} a+b)$ in different Al treatments compared with their controls were found at each time and by recovery in all cultivars (Fig. 3). At the end of $\mathrm{Al}$ treatments (48 h) and at the highest $\mathrm{Al}$ treatment $(100 \mu \mathrm{M} \mathrm{Al})$, a statistically significant decrease in Chl $a+b$ was found in 'Legacy' (33\%) and 'Bluegold' (56\%; $P \leq 0.001)$. Nevertheless, after the recovery treatment, only

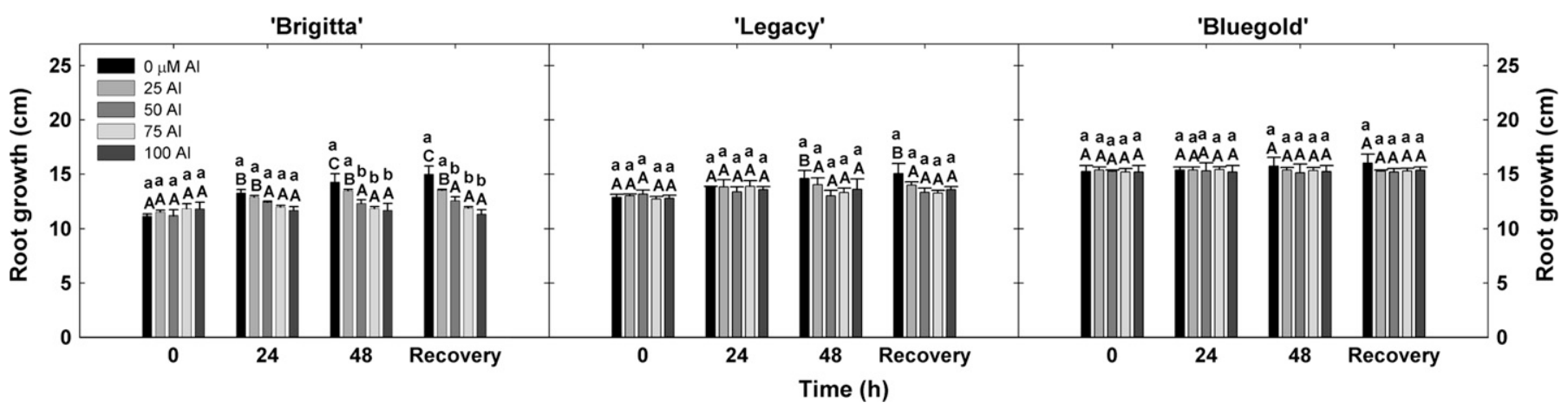

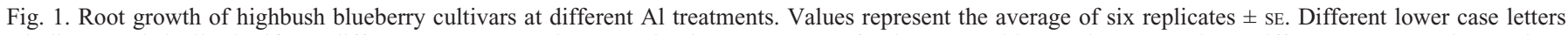

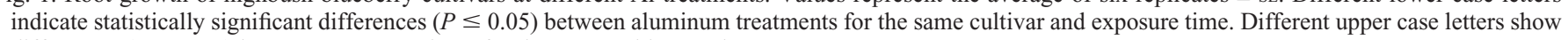
differences $(P \leq 0.05)$ between exposure times for the same cultivar and treatments.

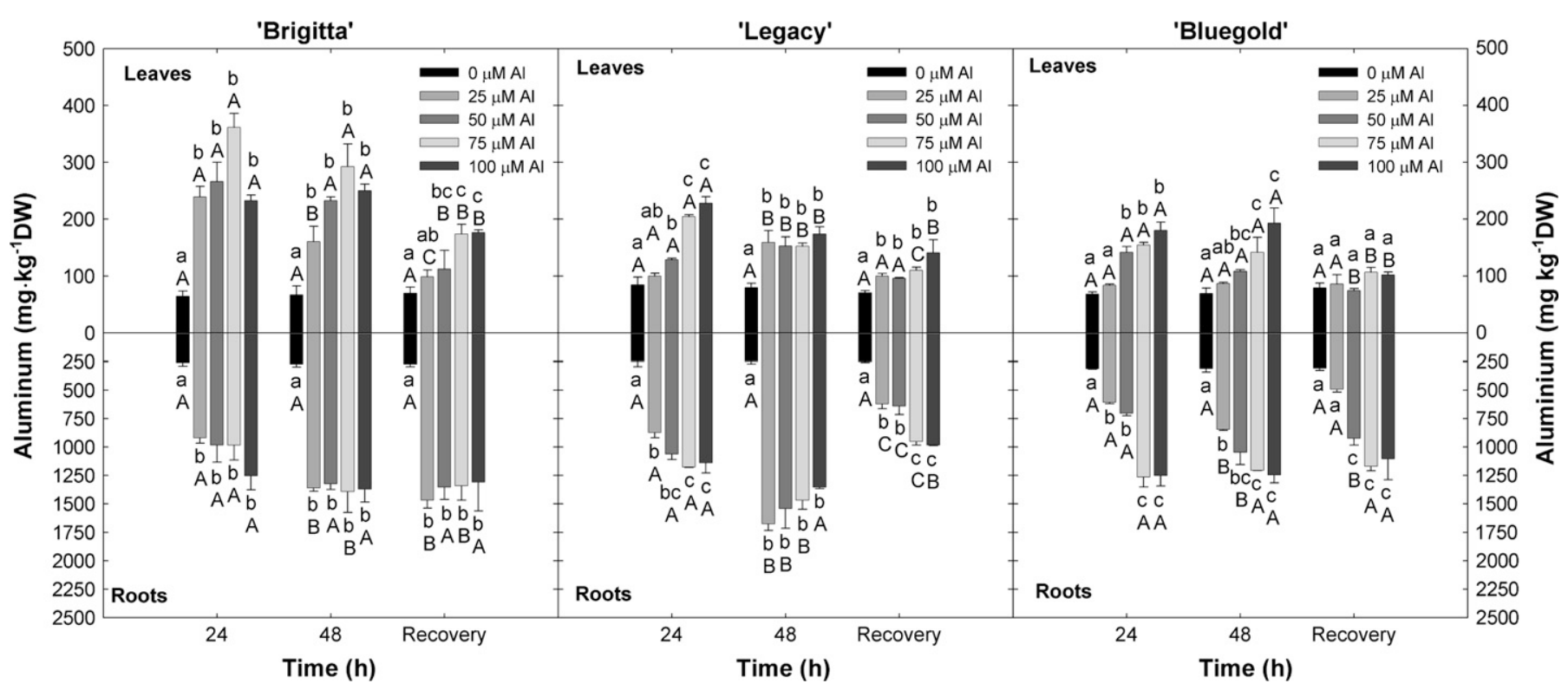

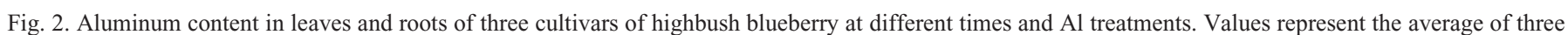
replicates \pm SE. Different lower case letters indicate statistically significant differences $(P \leq 0.05)$ between aluminum treatments for the same cultivar and exposure time. Different upper case letters show differences $(P \leq 0.05)$ between exposure times for the same cultivar and treatments. 


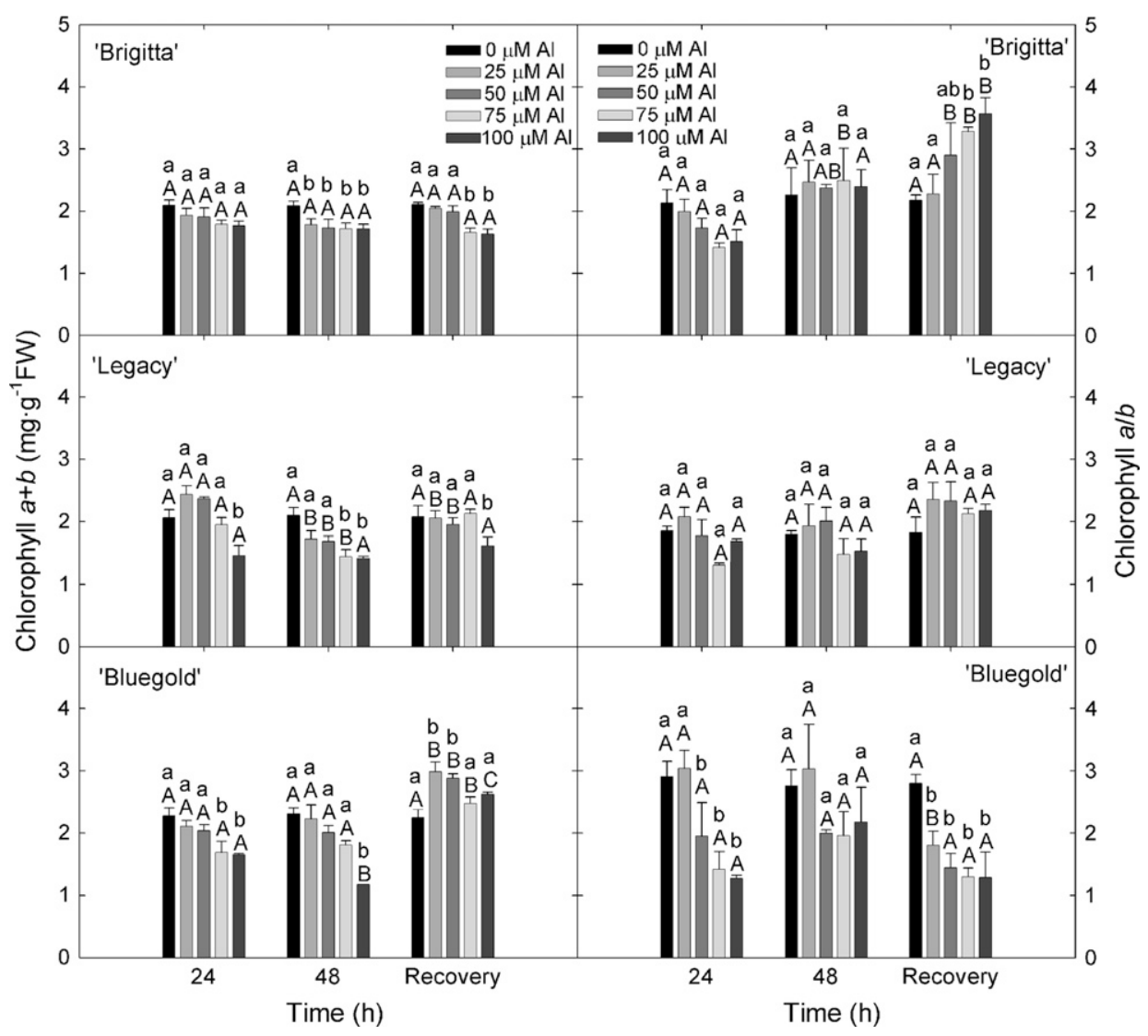

Fig. 3. Changes in chlorophyll pigments of three cultivars of highbush blueberry under aluminum stress. The panels on the left show total chlorophylls $(\mathrm{Chl} a+b)$ and the panels on the right show chlorophyll ratio $(\mathrm{Chl} a / b)$. Al exposure times were: $24 \mathrm{~h}, 48 \mathrm{~h}$, and recovery for $24 \mathrm{~h}$ without Al. Values represent the average of six replicates \pm SE. Different lower case letters indicate statistically significant differences $(P \leq 0.05)$ between aluminum treatments for the same cultivar and exposure time. Different upper case letters show differences $(P \leq 0.05)$ between exposure times for the same cultivar and treatments.

'Bluegold' reached and slightly surpassed the Chl $a+b$ content of the controls $(P<0.05$; Fig. 3). Chl $a+b$ content of each cultivar and Al content of leaves were negatively correlated. Moreover, a higher negative correlation between these parameters was found in 'Brigitta' $(\mathrm{r}=-0.7 ; P=0.001)$ and 'Legacy' $(\mathrm{r}=-0.6 ; P=0.001)$ than in 'Bluegold' $(\mathrm{r}=-0.4$; $P=0.02)$. A statistically significant interaction between time and Al treatments was detected for Chl $a+b$ content in 'Legacy' and 'Bluegold' ( $P=0.038$ and 0.001 , respectively).

Chlorophyll $a / b$ ratios (Chl $a / b)$ of 'Brigitta' and 'Bluegold' varied greatly with $\mathrm{Al}$ treatment and exposure time (Fig. 3). At $24 \mathrm{~h}$, 'Bluegold' showed a statistically significant decrease in $\mathrm{Chl} a / b$ with respect to the controls up to $50 \mu \mathrm{M} \mathrm{Al}(P<0.05)$, whereas in 'Legacy' and 'Brigitta', Chl $a / b$ ratios remained constant. No significant differences in $\mathrm{Chl} a / b$ of the cultivars at $48 \mathrm{~h}$ were found (Fig. 3). However, after the recovery treatment, this ratio increased significantly in 'Brigitta' subjected to the two highest $\mathrm{Al}$ treatments with respect to the control $(P<0.05)$. Chl $a / b$ decreased in 'Bluegold' and remained unchanged in 'Legacy' (Fig. 3). There was a significant inverse correlation between $\mathrm{Chl} a / b$ ratio and Al treatments in 'Bluegold' $(\mathrm{r}=-0.63$; $P<0.001)$. A statistically significant interaction between $\mathrm{Al}$ treatments and times was detected only in 'Brigitta' $(P=0.034)$.

Carotenoid content did not change in 'Bluegold' at each time and Al treatment, whereas in 'Legacy', a decrease in carote- noids was found at the highest $\mathrm{Al}$ treatments at $24 \mathrm{~h}(37 \%)$ and $48 \mathrm{~h}$ $(18 \%)$. In contrast, in 'Brigitta', carotenoids increased with treatments up to $50 \mu \mathrm{M} \mathrm{Al}$ at $24 \mathrm{~h}$ (34\%; Fig. 4). A negative, but not significant, correlation between carotenoids and $\mathrm{Al}$ treatment was found in 'Legacy' $(\mathrm{r}=-0.3$; $P=0.07$ ). No interaction between times and Al treatment was found for carotenoid contents $(P>0.151)$.

$\mathrm{F}_{\mathrm{v}} / \mathrm{F}_{\mathrm{m}}$ did not change in 'Brigitta' with Al treatments (Fig. 5). $\mathrm{F}_{\mathrm{v}} / \mathrm{F}_{\mathrm{m}}$ slightly decreased in 'Legacy' after $24 \mathrm{~h}(8 \%), 48 \mathrm{~h}(13 \%)$, and recovery treatment $(7 \%)$ compared with their controls $(P<0.05)$. In 'Bluegold', $\mathrm{F}_{\mathrm{v}} /$ $\mathrm{F}_{\mathrm{m}}$ decreased $(12 \%)$ at both times of $\mathrm{Al}$ exposure and after recovery treatment ( $8 \% ; P<0.05$; Fig. 5).

${ }_{\Phi}$ PSII and ETR of the three genotypes were differently affected at each Al treatment (Fig. 6). In 'Bluegold' and 'Legacy', a statistically significant decrease $(P<0.05)$ of ${ }_{\Phi}$ PSII and ETR values was found at each time in Al-treated with respect to Aluntreated plants. In 'Brigitta', this was true only after $24 \mathrm{~h}$ of Al treatment (Fig. 6). ${ }_{\Phi}$ PSII and ETR were lower in 'Bluegold' than in the other cultivars $(P<0.05)$. The best recovery of ${ }_{\Phi}$ PSII and ETR was shown by 'Brigitta', which, at $48 \mathrm{~h}$, showed an increase in these parameters with respect to the $24 \mathrm{~h} \mathrm{Al}$ treatment (Fig. 6). These values were very similar to the controls. A highly negative correlation between ${ }_{\Phi}$ PSII, ETR, and Al content in leaves was found in all cultivars $(\mathrm{r}=-0.7$ to $-0.85 ; P \leq 0.002)$. No interaction between time and Al treatment was found for ${ }_{\Phi}$ PSII and ETR $(P>0.391)$. NPQ of 'Brigitta' and 'Legacy' was unaffected by the Al treatment (Fig. 5). In 'Bluegold', a tendency to reduce NPQ under Al treatment was found after $24 \mathrm{~h}(P>0.05$; Fig. 5).

\section{Discussion}

The present data demonstrate that short-term Al stress produced differential effects on the chemical and physiological features of $V$. corymbosum cultivars. Al accumulation was higher in roots than in leaves in the three cultivars (up to 92\%). A good correlation between Al treatments and Al contents in both organs was found ( $\mathrm{r}=$ from 0.6 to $0.9 ; P \leq 0.05$ ). It appears that the best root growth of 'Brigitta' was concomitant with the better recovery of the photochemical parameters, suggesting that 'Brigitta' was the most Al-tolerant cultivar. Also, this cultivar accumulated more $\mathrm{Al}$ in its roots and leaves than the other cultivars. A high Al accumulation in leaves was directly associated with Al tolerance in Sorghum bicolor cultivars (Gonçalves et al., 1996). Some reports indicate that Al-tolerant genotypes accumulate less $\mathrm{Al}$ in their roots than the Alsensitive ones under $\mathrm{Al}$ exposure (Ma, 2005; Piñeros et al., 

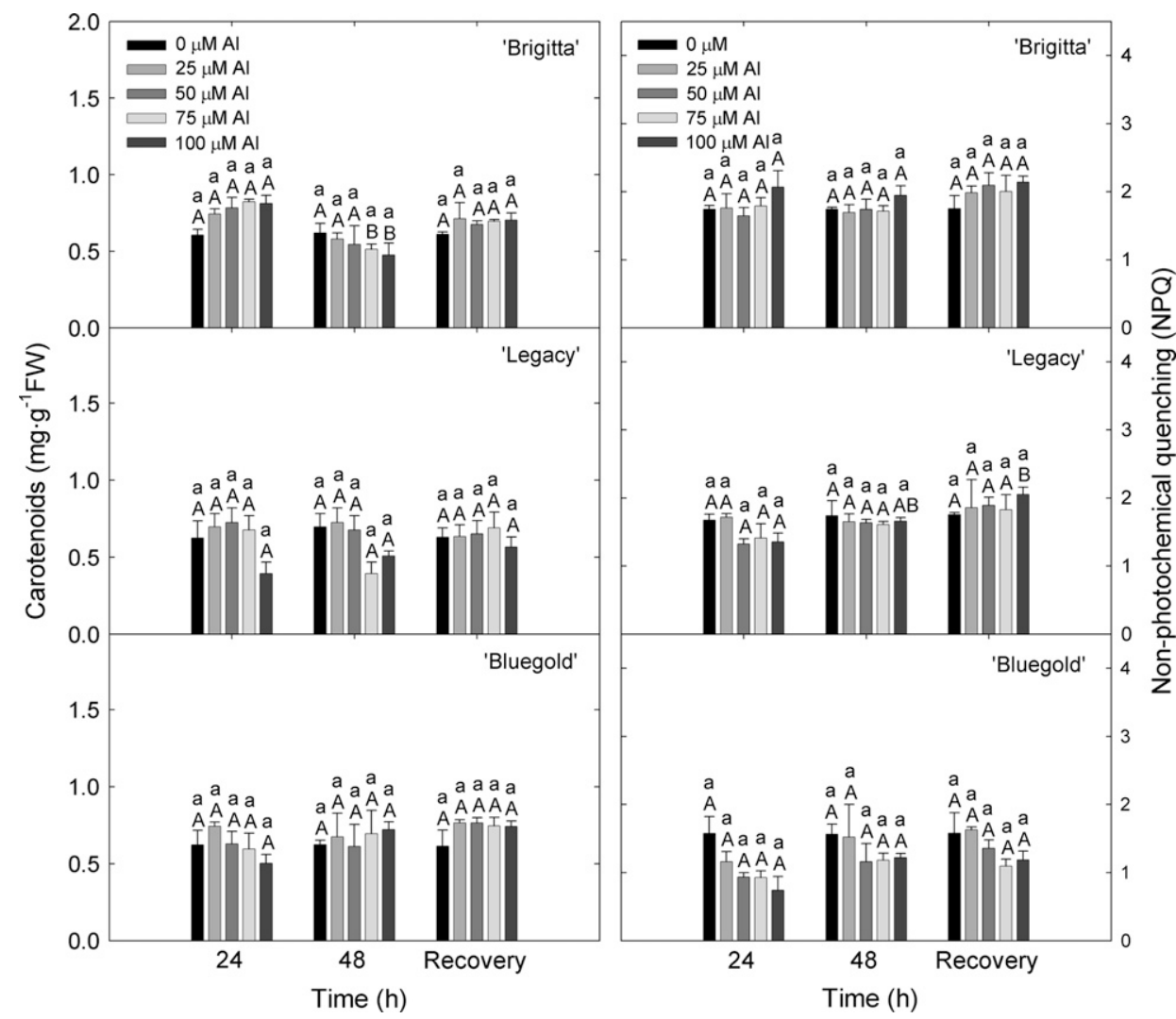

Fig. 4. Total carotenoids and nonphotochemical quenching (NPQ) of three cultivars of highbush blueberry under aluminum stress. Al exposure times were the same as in Fig. 3. Values represent the average of six replicates $\pm \mathrm{SE}$. Different lower case letters indicate statistically significant differences $(P \leq 0.05)$ between aluminum treatments for the same cultivar and exposure time. Different upper case letters show differences $(P \leq 0.05)$ between exposure times for the same cultivar and treatments.

2005). It is well established that the different $\mathrm{Al}$ accumulation in organs is highly dependant on the mechanism (exclusion or inclusion) used by plants to tolerate $\mathrm{Al}$ toxicity (Delhaize and Ryan, 1995; Kochian, 1995). Thus, the greatest Al accumulation in leaves found in 'Brigitta' supports our suggestion that 'Brigitta' could be considered the most Al-tolerant cultivar among those investigated in the present study.

Our cultivars showed up to $400 \mathrm{mg} \cdot \mathrm{kg}^{-1} \mathrm{Al}$ content in leaves per dry weight. This $\mathrm{Al}$ accumulation in Al-treated leaves was statistically significantly higher than their controls (over $60 \%$; $P \leq 0.05$ ), indicating translocation of $\mathrm{Al}$ from roots to leaves in all the cultivars. This translocation was higher in 'Brigitta' than in the other cultivars (around $70 \% ; P \leq$ 0.05 ). The $\mathrm{Al}$ content values exhibited by our highbush blueberry cultivars were similar to those reported in Saccharum officinarum leaves by Watt (2003). Sugarcane is considered more Al tolerant than other graminaceous crops (Hetherington et al., 1986).

The accumulation of $\mathrm{Al}$ in leaves differentially affected the photochemical efficiency of PSII $\left({ }_{\Phi} \mathrm{PSII}\right.$ and ETR) of the cultivars investigated (Fig. 6); 'Bluegold' was the most negatively affected by the $\mathrm{Al}$ treatments. Al-treated Citrus leaves also accumulated Al with a concomitant decrease of the photochemical efficiency of PSII with respect to the Al-untreated leaves (Chen et al., 2005b). Although the $\mathrm{F}_{\mathrm{v}} / \mathrm{F}_{\mathrm{m}}$ was in the normal ranges for healthy plants for the three cultivars under Al treatments $(0.7-0.8)$ (Björkman and Demmig, 1987), and a statistically significant decrease of this parameter was observed in 'Legacy' and 'Bluegold' (Fig. 2), indicating the same degree of disturbance of the photosynthetic apparatus under Al exposure. A statistically significant negative correlation between $\mathrm{Chl} a+b$ and Al treatment in leaves was found in all cultivars, with the highest being in 'Bluegold' $(\mathrm{r}=$ $-0.8 ; P=0.0003)$. The major decrease in Chl $a+b$ in 'Bluegold' suggests the possibility of selective chlorophyll photobleaching, resulting in a smaller fraction of absorbed light energy for electron transport (Habash et al., 1994; Miller and Carpentier, 1991). Peixoto et al. (2002) found similar results in S. bicolor cultivars where $\mathrm{Chl} a+b$ was substantially decreased after $48 \mathrm{~h}$ of $\mathrm{Al}$ exposure. Chlorophyll $a / b$ ratio decreased markedly under Al treatment in 'Bluegold' $(80 \%)$. These decreases reflect a reduction in the chlorophyll antenna size

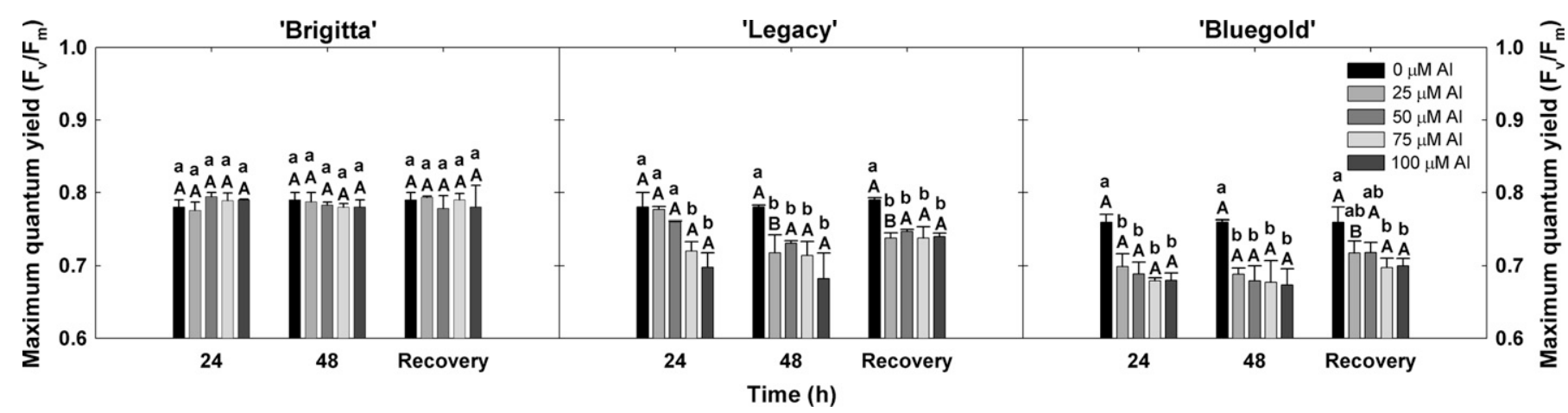

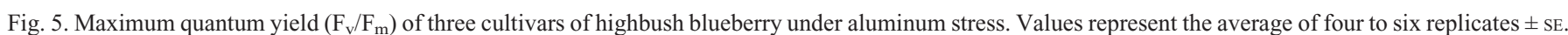
Different lower case letters indicate statistically significant differences $(P \leq 0.05)$ between aluminum treatments for the same cultivar and exposure time. Different upper case letters show differences $(P \leq 0.05)$ between exposure times for the same cultivar and treatments. 

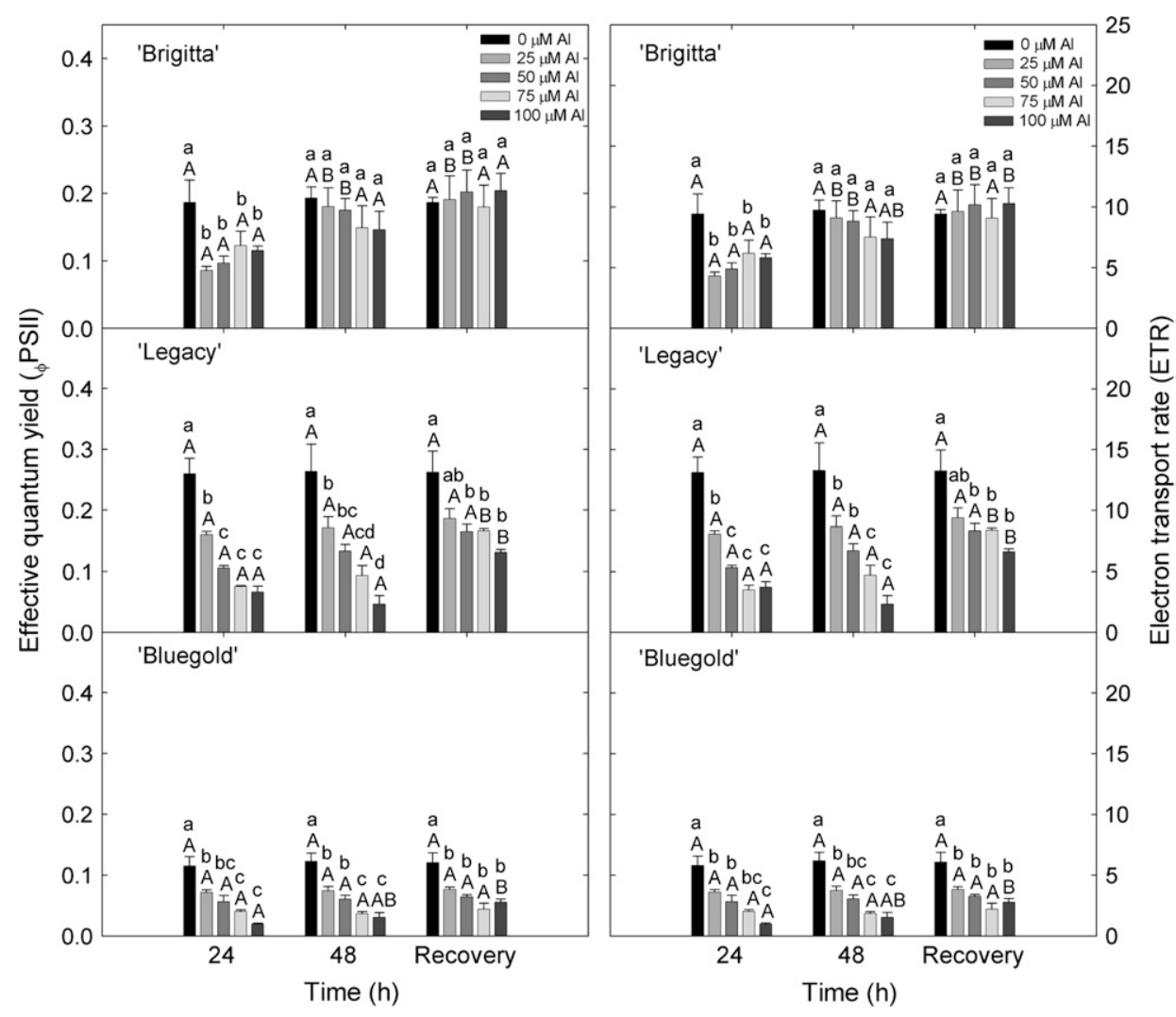

Fig. 6. Changes in the effective quantum yield ${ }_{(}$PSII) and electron transport rate (ETR) of three cultivars of highbush blueberry at different times under aluminum stress. Al exposure times were the same as in Fig. 3. Values represent the average of four to six replicates \pm SE. Different lower case letters indicate statistically significant differences $(P \leq 0.05)$ between aluminum treatments for the same cultivar and exposure time. Different upper case letters show differences $(P \leq 0.05)$ between exposure times for the same cultivar and treatments.

The thermal energy dissipation measured as NPQ did not present any variation between the control and Al-treated leaves, with the exception of 'Bluegold'. In this cultivar, a decrease of NPQ at all treatments and exposure times was found. Similar results were observed in the salt-acclimated halophyte Artemisia anethifolia ( $\mathrm{Lu}$ et al., 2003). These authors suggested that other metabolic pathways such as the water-water cycle, Mehler reaction, and photorespiration in Al-treated leaves may be upregulated to cope with the increased excess of excitation energy. In our study, NPQ did not correspond well with changes in carotenoid content. The relationship between NPQ and carotenoid content is controversial. It has been reported that changes in NPQ correlate closely and directly with changes in carotenoid pigments (Bilger and Björkman, 1990; Demmig-Adams and Adams, 1996); however, it has also been found that carotenoids may be unrelated to NPQ (Chen et al., 2005b; Johnson et al., 1993).

It is accepted that PSII is the most vulnerable part of the photosynthetic apparatus to stress-induced

of the photosystems and might protect the photosystems from photoinhibition by reducing energy delivery to the reaction centers (Adams et al., 2004). This change in chlorophyll antenna size is probably a strategy to reduce light absorption and avoid possible damage to the photosystems due to $\mathrm{Al}$ stress. Interestingly, at the beginning of the $\mathrm{Al}$ treatment, the chlorophyll antenna size was also reduced in 'Brigitta' (around 60\%), whereas after $48 \mathrm{~h}$ of Al treatment, a chlorophyll antenna size similar to the controls was obtained concomitantly with the maintenance of ${ }_{\Phi}$ PSII (Fig. 6). This suggests a fast acclimation of this cultivar's photosynthetic apparatus to Al stress supported by favorable root growth. A similar photoprotective strategy has been reported for evergreen species under other types of stress (Adams and Barker, 1998; Adams et al., 2004; Savitch et al., 2002).

Carotenoids play an essential role in protecting the photosynthetic apparatus against the harmful effects of light and oxygen, dissipating the excess light as heat in the antenna pigment complexes (Demmig-Adams and Adams, 1996; Niyogi et al., 1998). Our results showed similar carotenoid contents in all treatments in 'Bluegold', but a slight decrease in 'Legacy' by $\mathrm{Al}$ treatment was found at both times. In contrast, an increase in carotenoids was found in 'Brigitta' at the highest Al treatment with respect to the control after $24 \mathrm{~h}$. This carotenoid increase was related with a decrease of photochemical parameters, suggesting that this cultivar can favor the heat dissipation pathway and thus avoid PSII photoinhibition (Demmig-Adams and Adams, 1996). damage. Therefore, the photochemical parameters of PSII are indicative, under many conditions, of the overall rate of photosynthesis (Genty et al., 1989). They give us the potential to estimate photosynthetic performance and, thereby, plant productivity under different environmental conditions (Maxwell and Johnson, 2000). ${ }_{\Phi}$ PSII and ETR substantially decreased in 'Legacy' (around 73\%) and 'Bluegold' (around $83 \%$ ), without a total recovery of these parameters, especially in 'Bluegold' (Fig. 6). The photochemical parameters in 'Bluegold' were lower even under the control condition compared with the other cultivars. One possible explanation is that 'Bluegold' has already passed the fast-growing stage as evidenced by the absence of root growth even without $\mathrm{Al}$ treatment (Fig. 1). This was not the case in 'Brigitta' and 'Legacy' (Fig. 1). Another explanation is that 'Bluegold' may be intrinsically less efficient at managing its energy for photochemical processes than the others cultivars, which is even more noticeable with $\mathrm{Al}$ treatments. This cultivar-specific behavior may reflect lower productivity with respect to the other cultivars. In this respect, 'Brigitta' and, to a lesser extent, 'Legacy' managed the absorbed energy and tolerated $\mathrm{Al}$ exposure better than 'Bluegold' under short-term Al stress. Thus, as a first approximation, we could expect that 'Brigitta' is the best-qualified cultivar to develop in acidic soils with $\mathrm{Al}$ toxicity. Nevertheless, further investigation of the long-term $\mathrm{Al}$ response will be necessary because there exist time-dependent adjustment mechanisms. However, the current results also demonstrated that all $\mathrm{Al}$ treatments were toxic for 'Bluegold', 
showing its high sensitivity to Al stress. In contrast, the Al toxicity level for 'Brigitta' and 'Legacy' was $100 \mu \mathrm{M}$. Thus, the Al toxicity levels for blueberries depend on the genotype studied. The knowledge of this work is fundamental to selecting Al-tolerant highbush blueberry cultivars, which will permit better sustainable horticultural systems in acidic soils where Al toxicity is a major problem.

\section{Literature Cited}

Adams, W.W., III and D.H. Barker. 1998. Seasonal changes in xanthophyll cycle-dependent energy dissipation in Yucca glauca Nuttall. Plant Cell Environ. 21:501-511.

Adams, W.W., III, C.R. Zarter, V. Ebbert, and B. Demmig-Adams. 2004. Photoprotective strategies of overwintering evergreens. Bioscience 54:41-49.

Barceló, J. and C. Poschenrieder. 2002. Fast root growth responses, root exudates, and internal detoxification as clues to the mechanisms of aluminum toxicity and resistance: A review. Environ. Expt. Bot. 48:75-92.

Bilger, W. and O. Björkman. 1990. Role of the xanthophyll cycle in photoprotection elucidated by measurement of light-induced absorbance changes, fluorescence and photosynthesis in Hedera canariensis. Photosynth. Res. 25:173-175.

Björkman, O. and B. Demmig. 1987. Photon yield of $\mathrm{O}_{2}$ evolution and chlorophyll fluorescence characteristics at $77 \mathrm{~K}$ among vascular plants of diverse origins. Planta 170:489-504.

Bolan, N.S., D. Adriano, and D. Curtin. 2003. Soil acidification and liming interactions with nutrient and heavy metals transformations and bioavailability. Adv. Agron. 78:215-272.

Borie, F. and R. Rubio. 2003. Total and organic phosphorus in Chilean volcanic soils. Gayana Botanica 60(1):69-78.

Chen, L.S. 2006. Physiological responses and tolerance of plant shoot to aluminum toxicity. J. Plant Physiol. Mol. Biol. 32:143-155.

Chen, L.S., Y.P. Qi, and X.H. Liu. 2005b. Effects of aluminum on light energy utilization and photoprotective systems in citrus leaves. Ann. Bot. (Lond.) 96:35-41.

Chen, L.S., Y.P. Qi, B.R. Smith, and X.H. Liu. 2005a. Aluminuminduced decrease in $\mathrm{CO}_{2}$ in citrus seedlings is unaccompanied by decreased activities of key enzymes involved in $\mathrm{CO}_{2}$ assimilation. Tree Physiol. 256:317-324.

Dahlgren, R.A., M. Saigusa, and F.C. Ugolini. 2004. The nature, properties and management of volcanic soils. Adv. Agron. 82:113182.

Delhaize, E. and P.R. Ryan. 1995. Aluminum toxicity and tolerance in plants. Plant Physiol. 107:315-321.

Delhaize, E., S. Craig, C.D. Beaton, R.J. Bennet, V.C. Jagadish, and P.I. Randall. 1993. Aluminum tolerance in wheat (Triticum aestivum) I. uptake and distribution of aluminum in roots apices. Plant Physiol. 103:685-693.

Demmig-Adams, B. and W.W. Adams, III. 1996. The role of xanthophyll cycle carotenoids in the protection of photosynthesis. Trends Plant Sci. 1:21-26.

Genty, B., J.M. Briantais, and N.R. Baker. 1989. The relationship between the quantum yield of photosynthetic electron transport and quenching of chlorophyll fluorescence. Biochim. Biophys. Acta 990:87-92.

Giannakoula, A., M. Moustakas, P. Mylona, I. Papadakis, and T. Yupsanis. 2008. Aluminum tolerance en maize is correlated with increased levels of mineral nutrients, carbohydrates and proline, and decreased levels of lipid peroxidation and $\mathrm{Al}$ accumulation. J. Plant Physiol. 165(4):385-396.

Gonçalves, J.F.C., J. Cambraia, R. Sant'Anna, and S. Pacheco. 1996. Aluminum and zinc effects on the metabolism of ribonucleic acid in two sorghum cultivars. Braz. J. Plant Physiol. 8:81-86.

Guerrero, J.A. 2006. Capacidad antioxidante, fenoles y antocianinas totales e inhibición de Botrytis cinerea Pers. Ex Fr. por extractos crudos de fruta de cultivares de arándano alto (Vaccinium corymbo- sum L.) según localidad de la zona Sur de Chile. PhD Thesis.. Universidad Austral de Chile, Valdivia, Chile.

Habash, D.Z., B. Genty, and N.R. Baker. 1994. The consequences of chlorophyll deficiency for photosynthetic light use efficiency in a single nuclear gene mutation of cowpea. Photosynth. Res. 42:17-25. Hede, A.R., B. Skovmand, and J. López-Cesati. 2001. Acid soil and aluminum toxicity, p. 172-182. In: M.P. Reynolds, J.J. OrtizMonasterio, and A. Mchab (eds.). Application of physiology in wheat breeding. International Maize and Wheat Improvement Center (CIMMYT) Staff Publications Collection, Mexico D.F., Mexico.

Hetherington, S.J., C.J. Asher, and F.C.P. Blamey. 1986. Tolerance of sugarcane to Al in soil and solution culture. Proc. Austral. Soc. Sugar Cane Technologists Congr. 63-68.

Hoagland, D.R. and D.I. Arnon. 1959. The water culture method for growing plants without soil. California Agr. Expt. Sta. 347:1-32.

Ireland, G. and P. Wilk. 2006. Blueberry production in northern NSW. Primefact 195. 10 Oct. 2008. <http://www.dpi.nsw.gov.au/_data/ assets/pdf_file/0005/90356/Blueberry-production-in-northernNSW.pdf $>$.

Jarvis, S.C. 1987. Laboratory studies of effects of lime on soluble Al, $\mathrm{Ca}, \mathrm{Mg}$ and $\mathrm{Mn}$ in a pelostagnogley soil. J. Soil Sci. 38:443-451.

Johnson, G.N., A.J. Young, J.D. Scholes, and P. Horton. 1993. The dissipation of excess excitation energy in British plant species. Plant Cell Environ. 16:673-679.

Kochian, L.V. 1995. Cellular mechanisms of aluminum toxicity and resistance in plants. Annu. Rev. Plant Physiol. Plant Mol. Biol. 46:237-260.

Lichtenthaler, H. and A.R. Wellburn. 1983. Determinations of total carotenoids and chlorophyll $a$ and $b$ of leaf extracts in different solvents. Biochem. Soc. Trans. 603:591-592.

Lu, C., N. Qiu, and Q. Lu. 2003. Photoinhibition and the xanthophylls cycle are not enhanced in the salt-acclimated halophyte Artemisia anethifolia. Physiol. Plant. 118:532-537.

Ma, J.F. 2005. Physiological mechanisms of Al resistance in higher plants. Soil Sci. Plant Nutr. 61:609-612.

Matsumoto, H. 2000. Cell biology of aluminum toxicity and tolerance in higher plants. Int. Rev. Cytol. 200:1-46.

Maxwell, K. and G.N. Johnson. 2000. Chlorophyll fluorescence: A practical guide. J. Expt. Bot. 51:659-668.

Miller, N. and R. Carpentier. 1991. Energy dissipation and photoprotection mechanisms during chlorophyll photobleaching in thylakoid membranes. Photochem. Photobiol. 54:465-472.

Mora, M., M. Alfaro, P.H. Williams, W. Stehr, and R. Demanet. 2004. Effect of fertilizer input on soil acidification in relation to growth and chemical composition of a pasture and animal production. J. Soil Sci. Plant Nutr. (Chile) 4:29-40.

Mora, M.L., M.A. Alfaro, S.C. Jarvis, R. Demanet, and P. Cartes. 2006. Soil aluminium availability and animal metabolism. Soil Use Mgt. 22:95-101.

Mora, M.L., R. Demanet, E. Vistoso, and F. Gallardo. 2005. Influence of sulfate concentration in mineral solution on ryegrass grown at different $\mathrm{pH}$ and aluminum levels. J. Plant Nutr. 28:1-16.

Moustakas, M., G. Ouzounidou, P.E. Eleftherios, and R. Lannoye. 1995. Aluminum effect on photosynthesis and elemental uptake in an aluminum-tolerant and non-tolerant wheat cultivar. J. Plant Nutr. 18:669-683.

Niyogi, K.K., A.R. Grossmn, and O. Björkman. 1998. Arabidopsis mutants define a central role of the xanthophylls cycle in the regulation of photosynthetic energy conversion. Plant Cell 10:1121-1134.

Peixoto, P.H.P., F.M. Da Matta, and J. Cambraia. 2002. Responses of the photosynthetic apparatus to aluminum stress in two sorghum cultivars. J. Plant Nutr. 25:821-832.

Pereira, W.E., D.L. de Siqueira, C.A. Martínez, and M. Puiatti. 2000. Gas exchange and chlorophyll fluorescence in four citrus rootstocks under aluminum stress. J. Plant Physiol. 157:513-520.

Piñeros, M.A., J.E. Shaff, S. Manslank, A. Carvalho, M. Vera, and L.V. Kochian. 2005. Aluminum resistance in maize cannot be solely 
explained by root organic exudation: A comparative physiological study. Plant Physiol. 137:231-241.

Quinn, G.P. and M.J. Keough. 2006. Split-plot and repeated measures designs: Partly nested analyses of variance, p. 301-338. In: G.P. Quinn and M.J. Keough (eds.). Experimental design and data analyses for biologist. Cambridge University Press, Edinburgh, UK. Raman, H., J.S. Moroni, K. Sato, B.J. Read, and B.J. Scott. 2002. Identification of AFLP and microsatellite markers linked with an aluminum tolerance gene in barley (Hordeum vulgare L.). Theor. Appl. Genet. 105:458-464.

Rao, I.M. and G.R. Cramer. 2003. Plant nutrition and crop improvement in adverse soil conditions, p. 270-303. In: M.J. Chrispeels and D.E. Sadava (eds.). Plant, genes and crop biotechnology. 2nd ed. Jones and Bartlett, Sudbury, MA.

Rengel, Z. 1996. Uptake of aluminum by plant cells. New Phytol. 134:389-406.

Reyes-Díaz, M., M. Alberdi, F. Piper, L.A. Bravo, and L.J. Corcuera. 2005. Low temperature responses of Nothofagus dombeyi (Mirb.) Blume and Nothofagus nitida (Phil.) Krasser, two evergreen species from south central Chile. Tree Physiol. 25:1389-1398.
Sadzawka, A., R. Grez, M.L. Mora, N. Saavedra, M.A. Carrasco, H. Flores, and C. Rojas. 2004. Métodos de análisis de tejidos vegetales. Comisión de Normalización y Acreditación, Sociedad Chilena de la Ciencia del Suelo, Editorial Salesianos Impressores, Santiago, Chile.

Savitch, L.V., E.D. Leonardos, M. Krol, S. Jansson, B. Grodzinski, N.P.A. Hüner, and G. Öquist. 2002. Two different strategies for light utilization in photosynthesis in relation to growth and cold acclimation. Plant Cell Environ. 25:761-771.

Tamás, L., J. Hutttová, I. Mistrík, and B. Simonovicová. 2006. Aluminum-induced drought an oxidative stress in barley roots. J. Plant Physiol. 163:781-784.

von Uexkull, H.R. and E. Mutert. 1995. Global extent, development and economic impact of acid soils, p. 5-19. In: R.A. Date, N.J. Grundon, G.E. Rayment, and M.E. Probet (eds.). Plant-soil interactions at low pH: Principles and management. Kluwer Academic Publishers, Dordrecht, The Netherlands.

Watt, D.A. 2003. Aluminum-responsive genes in sugarcane: Identification and analysis of expression under oxidative stress. J. Expt. Bot. 54:1163-1174. 